\title{
TERRA ASTER画像を用いた有明海湾奥部の 水質推定手法について \\ ON THE ESTIMATION METHOD FOR WATER QUALITY \\ IN THE INNERMOST PART OF THE ARIAKE SEA BY USING TERRA-ASTER IMAGES
}

\author{
大串浩一郎1, 2 ・荒木宏之 3 \\ Koichiro OHGUSHI and Hiroyuki ARAKI \\ 1正会員 工博 佐賀大学助教授 理工学部都市工学科 (广 $840-8502$ 佐賀市本庄町 1 番地) \\ 2有明海総合研究プロジェクト (下 840-8502 佐賀市本庄町 1 番地) \\ 3正会員 工博 佐賀大学教授 低平地研究センター ( $740-8502$ 佐賀市本庄町 1 番地)
}

\begin{abstract}
The method to estimate the water quality of innermost part of the Ariake Sea by the TERRA-ASTER sensor is studied. To make a model for estimating water quality from artificial satellite images, the images whose dates and times are almost same as those of observations were carefully chosen. The estimation models for not only the water transparency and temperature but also the chlorophyll-a are developed through regression analysis. The obtained results are compared with those of the LANDSAT-TM/ETM+ and the performance of the TERRA-ASTER is confirmed.
\end{abstract}

Key Words : Remote sensing; water quality monitoring; Ariake Sea; innermost part; shallow sea; tidal flat; TERRA-ASTER sensor.

1 .はじめに

有明海は、九州の4県に囲まれた半閉鎖性水域で、主 に早崎瀬戶を通じて外海の東シナ海と海水交換を行って いる。この水域の面積は約 $1,700 \mathrm{~km}$ 、平均水深は約 $20 \mathrm{~m}$ である。有明海は約6nの潮位差を有し国内最大である。 この大きな゙潮位差により海岸には日に2回広大な干潟が 現れる。我力国の約40\%の干潟がこの有明海に集中して おり、樣々な生物か泩息する最も生物生産が活発な゙海の 1つとなった。弚のため、ここの水揚げ高は非常に大き く、漁師たちはこの海のことを「宝の海」と呼んでいる。 しかしながら、沿岸域の開発等により、有明海は徐々に 污れてきた。近年、光のため二枚貝の漁獲高は激减し、 2000年には養殖ノリが大打撃を受けた。このような異変 が何故起きたのかについはまた詳しく分かっていない。 乥こで、この問題に答えるために、この内湾環境の長 期的モニタリングが重要となってくる。しかし、この広 い海域の調査を長期に行うには、非常に大きい時間とコ ストか要求される。したがって、広い海域をモニタリン グするための効果的な手法の1つとして、衛星リモート センシングか洧力となる。

Ganら ${ }^{11}$ やChgushi ら ${ }^{2,31}$ は、現地調査データと地球観測
衛星LANDSATのTMETM画像を用いて有明海の透明度、海 面温度、クロロフィルaなどの平面分布を推定するため のモデルを開発してきた。

一方、桐本ら ASTERセンサにより、諫早湾のSSの分布状況を観察する 試みを実施している。

本論文では、LANDSATより空間解像度やバンド数で有 利なTERPA ASTER衛星画像を用いた、水質情報、特に透 明度、海水面温度やクロロフィルaの推定方法を検討し

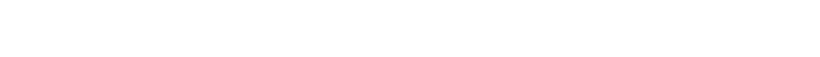
にさまざまな方法を検証し、LANDSAT- TMYETMによる推 定結果との比較検討を行った。

\section{TERRA ASTERセンサについて}

衛星リモートセンシングは1972年のLANDSAT1号打ち上 げ以来、地球を観測する目的で用いられてきた。NASAは、 近年顕著な地球規模の環境問題のメカニズムを説明する ためにEOSプロジェクト (Earth Observing SystemProject ) を立ち上げた。EOSプロジェクトの一環として地 球観測衛星TERRAが1999年に打ち上げられた。TERRAのプ ラットフォームには 5 種類のセンサカ㟷載されている。 
表- 1 TERRA ASTERセンサの観測波長域と空間解像度

\begin{tabular}{|c|c|c|c|}
\hline $\begin{array}{l}\text { 放射 } \\
\text { 計 }\end{array}$ & $\begin{array}{l}\text { バンド } \\
\text { 番号 }\end{array}$ & 波長域 $(\mu \mathrm{m})$ & $\begin{array}{c}\text { 空間解像度 } \\
(\mathrm{m})\end{array}$ \\
\hline \multirow{3}{*}{ VN R } & 1 & $0.52-0.60$ & \multirow{3}{*}{15} \\
\hline & 2 & $0.63-0.69$ & \\
\hline & 3 & $0.76-0.86$ & \\
\hline \multirow{6}{*}{ SWR } & 4 & $1.60-170$ & \multirow{6}{*}{30} \\
\hline & 5 & $2.145-2.225$ & \\
\hline & 6 & $2.185-2.225$ & \\
\hline & 7 & $2.235-2.286$ & \\
\hline & 8 & $2.295-2.365$ & \\
\hline & 9 & $2.360-2.430$ & \\
\hline \multirow{5}{*}{ TI R } & 10 & $8.125-8.475$ & \multirow{5}{*}{90} \\
\hline & 11 & $8.475-8.825$ & \\
\hline & 12 & $8.925-9.275$ & \\
\hline & 13 & 10. $25-10.95$ & \\
\hline & 14 & $10.95-11.65$ & \\
\hline
\end{tabular}

表 - 2 LANDSAT- TMセンサの観測波長域と空間解像度

\begin{tabular}{|c|c|c|}
\hline $\begin{array}{c}\text { バンド } \\
\text { 番号 }\end{array}$ & 波長域 $(\mu \mathrm{m})$ & $\begin{array}{c}\text { 空間解像度 } \\
(\mathrm{m})\end{array}$ \\
\cline { 1 - 2 } 1 & $0.45-0.52$ & \\
\cline { 1 - 2 } & $0.52-0.60$ & \multirow{2}{*}{30} \\
\cline { 1 - 2 } 3 & $0.63-0.69$ & \\
\hline 4 & $0.76-0.90$ & \\
\hline 5 & $1.55-1.75$ & 60 \\
\hline 6 & $10.4-12.5$ & 30 \\
\hline 7 & $2.08-2.35$ & \\
\hline
\end{tabular}

表 - 3 LANDSAT- ETMセンサの観測波長域と空間解像度

\begin{tabular}{|c|c|c|}
\hline $\begin{array}{c}\text { バンド } \\
\text { 番号 }\end{array}$ & 波長域 $(\mu \mathrm{m})$ & $\begin{array}{c}\text { 空間解像度 } \\
(\mathrm{m})\end{array}$ \\
\hline 1 & $0.45-0.52$ & \multirow{2}{*}{30} \\
\cline { 1 - 2 } 2 & $0.52-0.60$ & \\
\cline { 1 - 2 } 3 & $0.63-0.69$ & \\
\hline 4 & $0.76-0.90$ & \\
\hline 5 & $1.55-1.75$ & 60 \\
\hline 6 & $10.4-12.5$ & 30 \\
\hline 7 & $2.08-2.35$ & 15 \\
\hline 8 & $0.50-0.90$ & \\
\hline
\end{tabular}

ASTER ( Advanced Spaceborne Ther næl Enissi on and Ref I ecti on radi onet er ) はとのうちの1つのセンサで あり、我が国によって開発されている。ASTERセンサは、 LANDSAT- TMETMセンサの後継機としての強力な゙ンール となることか期待されている。ASTERセンサは、可視域 から熱赤外域まで14バンドという広いスペクトル範囲を カバーしている。ASTERは次の3つのサブシステムから 構成されている。すなわち、可視近赤外放射計（VNR）、

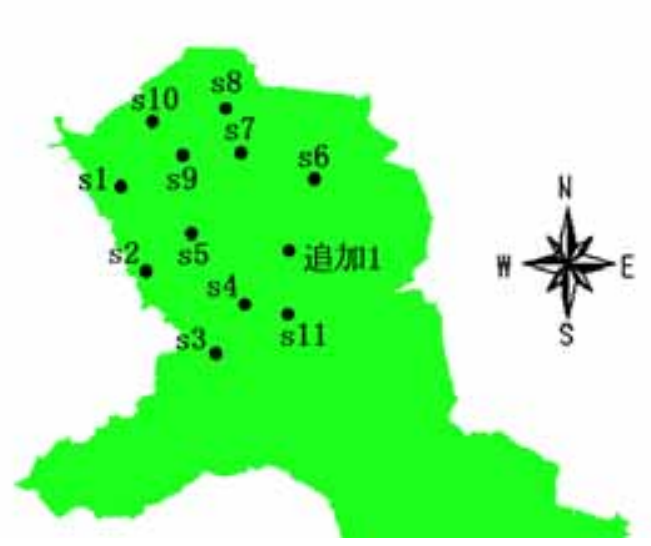

図-1 本研究で用いた有明海湾奥部における 水質観測地点

短波長赤外放射計（SWR）、光して熱赤外放射計

(TIR) である。VN Rは可視域から近赤外域まで力バー する空間解像度15mのンサである。一方、SWRは短波 赤外域を受け持ち、空間解像度は30mである。一番波長 の大きい熱赤外域はTI RC観測され、空間解像度は90m飞 なっている。光の概要を表 - 1 に示す。なお、比較のた めLANDSAT- TMならびにLANDSAT- ETMの概要も光れ光れ表 -2 , 3に示す。

\section{3. 研究方法}

有明海は我力国最大の潮位差を有するため、広い区域 で朝汐による規則的な干出力繰り返され、広大な干潟が 形成されている。ここは、生物にとっても最も活気に満 ちた場所であるとともに環境学的にも重要な所である。 また、本研究で使用するTERRA ASTER衛星画像は、バン ド数が多いことに加え、空間解像度が高いため、1枚の 画像で有明海全体をカバーすることはできない。以上の ような理由で、本研究では、研究対象地域として有明海 湾奥部に焦点を当て、解析することとした。

本研究で使用したTERRA ASTER画像は、有明海湾奥部 が含まれる2002/3/13、2002/9/21ならびに2004/12/15の 3シーンである。これらのデータを選んだ理由は、現地 観測（観測地点は図－1を参照）を同日同時刻に実施し ていることと、2002/3/13ならびに2002/9/21については、 LANDSAT- ETAの衛星画像力浰用可能であるため、光れ光 れの衛星から推定される水質指標の精度を比較検討する ことが可能であるためである。現地観測による観測項目 は、透明度、水温、塩分、クロロフィルaなどである。 これらの衛星画像は幾何補正ならびに大気補正を行うこ とで、お互いの比較か可能となる。幾何補正としては、 国土地理院発行の数值地図海岸線・行政界のベクトル データを参照画像として用いた。視程などの気象情報は 弚れ光れの画像に対する大気補正に用いた。以上の幾何 補正ならびに大気補正については、ERDAS I NAG NEなら びにATCOR というソフトウェアを用いて解析を行った。 前者のソフトウェアにより衛星画像のインポートならび 
に幾何補正を行い、後者のソフトウェアにより大気補 正を行った放射輝度情報の画像を取得した。次に、 LANDSAT- TMYETA画像データに対しては 7 つのバンド、 TERRA ASTER画像データに対しては、14のバンドのDN 值と実測値との回帰解析を統計解析ソフトウェアS PLUSを用いて行い、そこから得られる回帰式を用いて 有明海湾奥部の水質指標の推定分布図を作成した。

\section{4 . 回帰解析の結果}

水質指標として海水面温度、透明度、クロロフィル aならびに塩分を選び、観測值に対して回帰解析を 行った。TERPA ASTERについては前述の通り 3 枚の シーンを用い、一方、LANDSAT- TMETMAについては 8 枚の画像を解析に用いた。これらの画像から水質を推 定する推定式の精度を比較するためにLANDSAT画像の 大気補正についても、大気補正プログラムATCORを用 いて再度補正作業を行った。关の理由は、LANDSATTMETA画像の大気補正については、以前、LOARAN $7^{7}$ を用いた補正を行っていたが、今回、TERRA ASTER画像 に施す補正と全く同じ補正を行うことで正確な比較が 可能であると考えたためである。

\section{(1) 海水面温度}

有明海の水温は、冬季には湾口部で10〜 $13^{\circ} \mathrm{C}$ 、湾奥 部で8 1 $10^{\circ} \mathrm{C}$ を示し、夏季には前者て約 $26^{\circ} \mathrm{C}$ 、後者で28

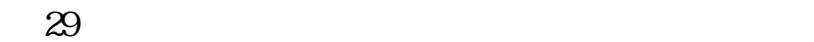
像同士の比較や推定モデルの開発に利用することが可 能である。产の理由は、光の時の大気の影響を除去す ることができれば、地表面あるいは水表面自身の状態 を直接比較することが可能になるからである。

回帰解析によりASTER画像による海水面温度 (SST) 推定のための回帰式が以下のように得られた。

$$
\begin{array}{r}
S S T=\exp \left(k+\alpha_{1} D N_{1}+\alpha_{2} D N_{2}+\alpha_{3} D N_{3}+\alpha_{6} D N_{6}\right. \\
\left.+\alpha_{7} D N_{7}+\alpha_{8} D N_{8}+\alpha_{9} D N_{9}+\alpha_{13} D N_{13}\right)
\end{array}
$$

ここで、各定数は光れ光れ、 $k=3.2134 ， \alpha_{1}=0.0014$, $\alpha_{2}=-0.0228, \alpha_{3}=0.0365, \alpha_{6}=0.0404, \alpha_{7}=-0.3010$, $\alpha_{8}=0.1429, \quad \alpha_{9}=0.0760, \quad \alpha_{13}=0.0090$ であり、 $D N_{i}(i=1,2, \ldots)$ は大気補正後のバンド $i$ のデジタルナン バーである。熱赤外バンドについては、バンド13のみを 使用しているが、他の熱赤外バンドも使用したモデルと 比較して結果の差がほとんど出てこなかったので省略す ることとした。これは、他の水質指標でも同樣である。

図 - 2(a) はTERPA ASTER画像から得られた推定海水面 温度と観測值の比較のための散布図である。この図の中 でさまざまな季節のデータが含まれているが、これにつ いては既往の研究1)の中で、1つの季節のみを回帰解析 に用いて得られたモデルでは、他の時期の推定か困難で あり、複数の季節の情報を取り込むことでより精度が向

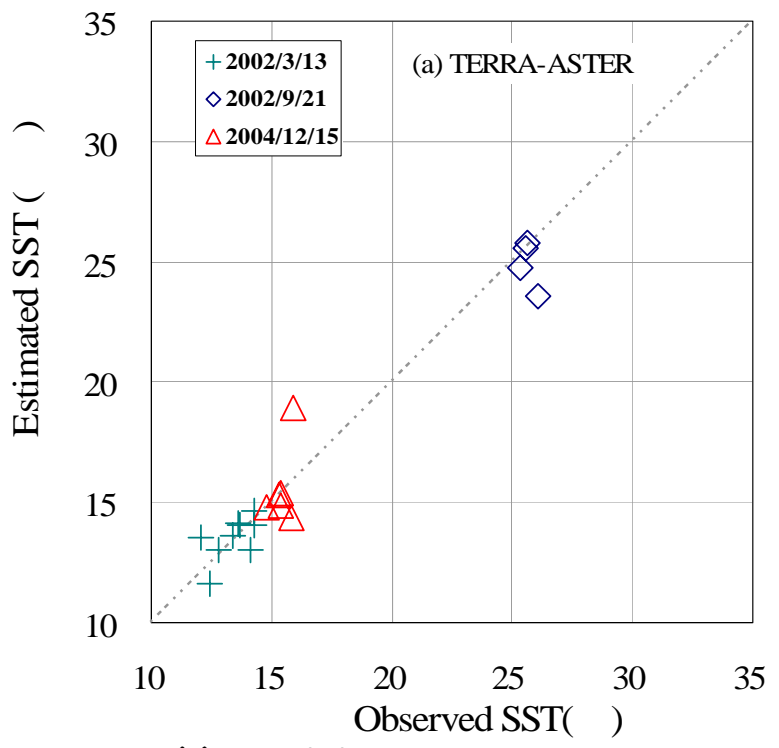

図 - 2(a) TERPA ASTER画像により得られた推定 海水面温度と観測值の比較

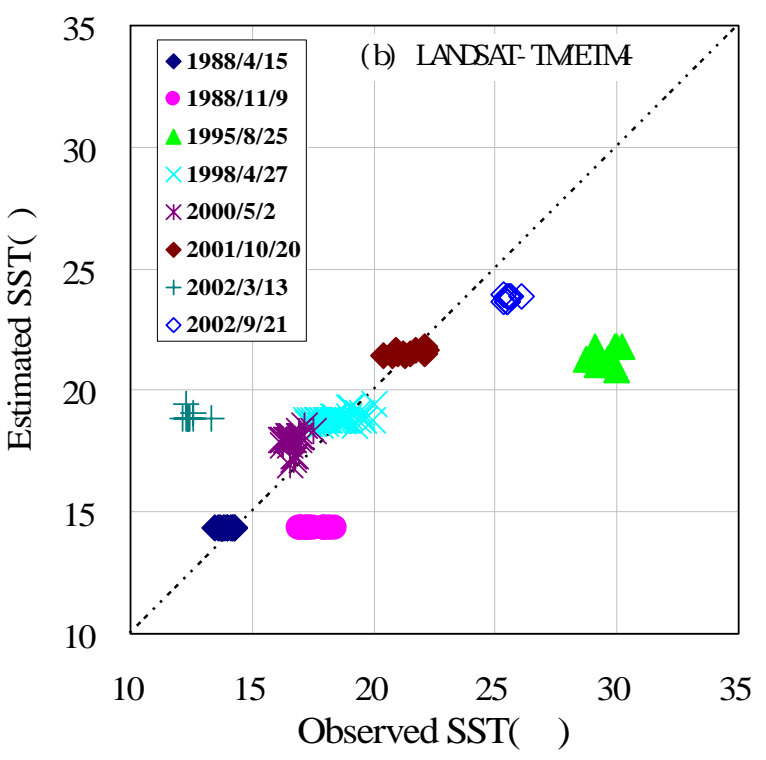

図－2(b) LANDSAT- TMYETM画像によって得られ た推定海水面温度と観測值の比較

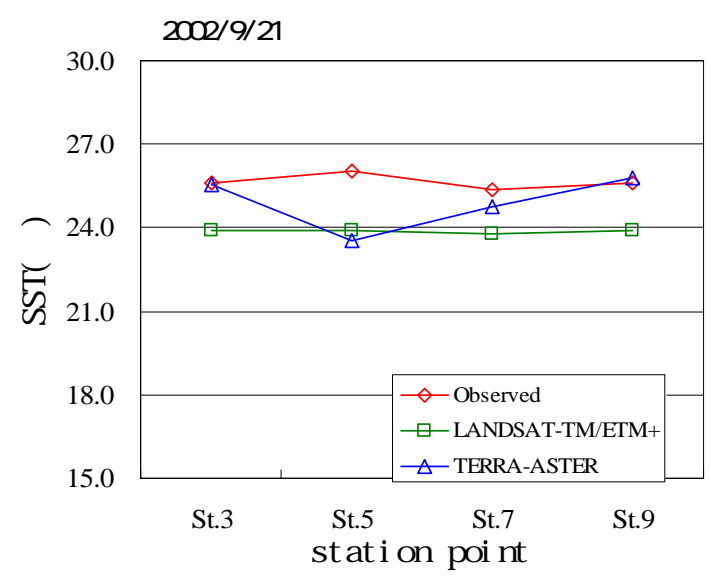

図 - 3 海水面温度の推定精度の比較 
上することと、さらに、大気補正を適切に行えば、多時 期のデータを同じように扱えるということか理由として

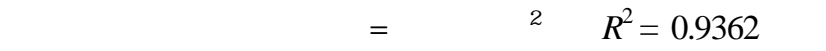
る。一方、図 - 2 (b) はLANDSAT- TMETMA画像による結果

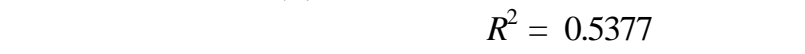
LANDSAT- TMYETMに比べてTERRA ASTER の推定精度が格 段に向上した理由としては、この衛星画像の高い空間解 像度とスペクトル解像度の両方か影響したと考えられる。 LANDSATでは、1995/8/25や2002/3/13の水温の推定精度 が悪いが、これは、LANDSATのモデルでバンド6のみ用 いていたためであると考えられる。ASTERでは可視域か ら近赤外域までの情報を取り入れたことも精度向上に役 立ったと思われる。LANDSATの場合、同樣のバンドをモ デルに用いた解析も行っているが、敢えてモデルに取 り込むまでの精度向上にはつながらなかつた。关の理由 としては空間解像度の問題があげられる。図 - 3は、実 際に現地の観測地点 (図 - 1参照) て観測した水温と推 定値との比較の図である。地点番号が連続でないのは、 3つのデータの比較ができない地点を除いたためである。 TERPA ASTERIにって推定された水温かLLANDSAT- TMETM の光れより格段に精度向上しているのは予見された通り である。

\section{(2) 透明度}

透明度 (SDD) は、水の清澄度や水の中に含まれる懸 濁性物質や有機物による光の減衰の度合いを表す指標で、 通常、セッキ板と呼ばれる直径30cn炷どの白い円板が海 水中のどの深さまで肉眼で見えるかを畹位で表した ものである。有光層の厚さは、普通二の透明度の $2 \sim 3$ 倍であると言われている。この透明度の值は、植物プラ ンクトンの生産のための最も重要なパラメータの1つで ある。この透明度は、有明海の湾奥ではほとんど 1 年中 纲以下であるのに対し、湾口部では8nに達する(ただし、 夏季の降水期には5n位まて低下する)。近年、有明海の 透明度が上昇しているとの報告か幾つかの報告書でなさ

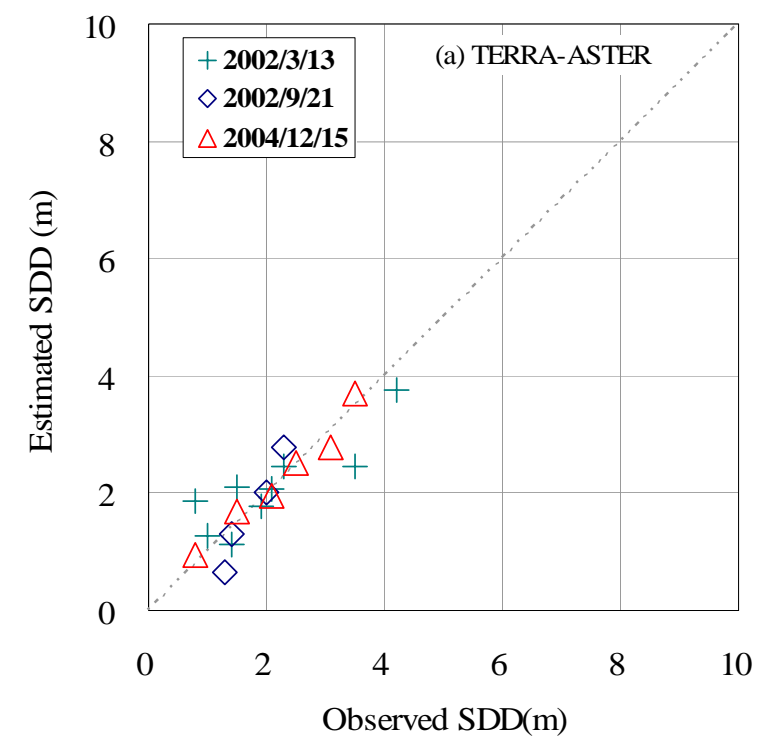

図 - 4 (a) TERRA ASTER画像による推定透明度と 観測值の比較

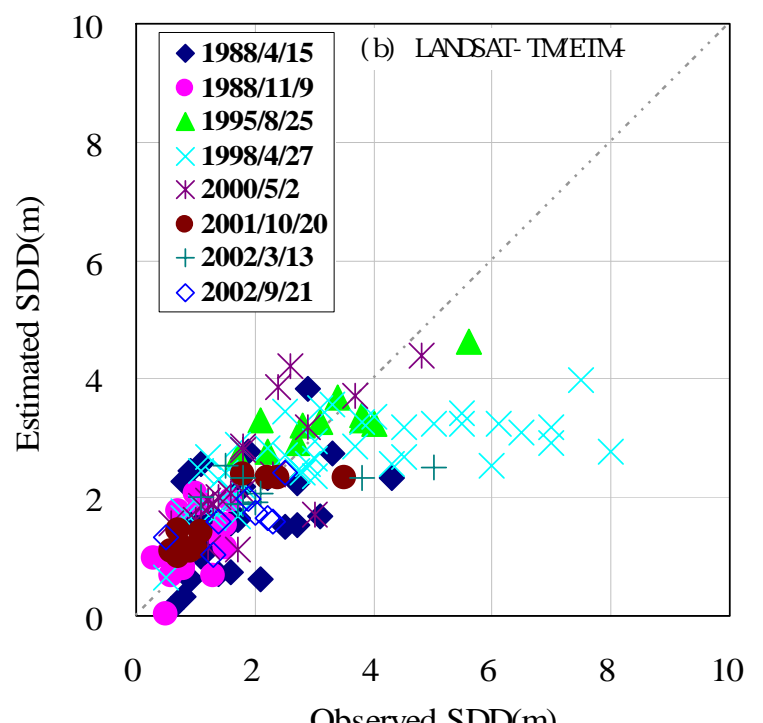

Observed SDD(m)

図 - 4 (b) LANDSAT- TMETM画像による推定透明 度と観測值の比較
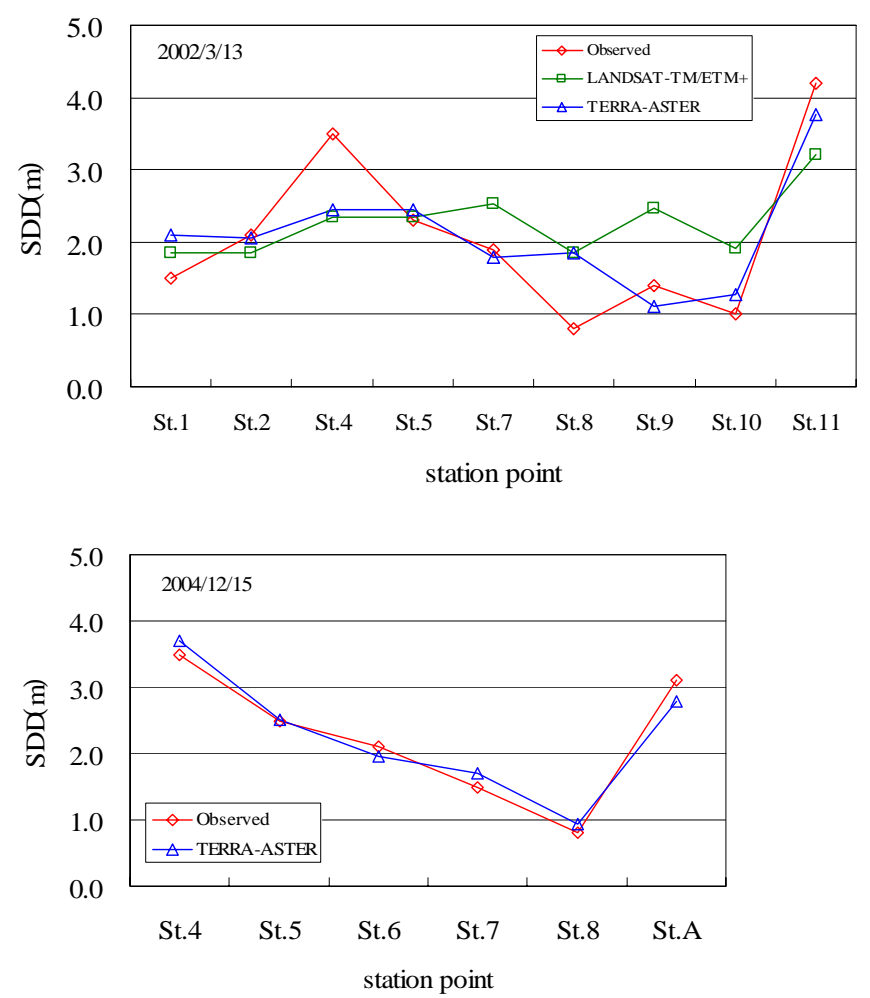

図 - 5 透明度の推定精度の比較

れている8 。

海水面温度と同樣の線形回帰解析により、ASTER画像 による透明度 (SDD) を推定する回帰式が以下のように 得られた。

$$
\begin{aligned}
S D D=\ell & +\beta_{1} D N_{1}+\beta_{2} D N_{2}+\beta_{3} D N_{3}+\beta_{6} D N_{6} \\
& +\beta_{7} D N_{7}+\beta_{8} D N_{8}+\beta_{9} D N_{9}+\beta_{13} D N_{13}
\end{aligned}
$$

ここで、各定数は光れ光れ、 $\ell=12.1623, \beta_{1}=0.0220$, $\beta_{2}=-2.7063, \quad \beta_{3}=-0.7135, \beta_{6}=0.3033, \beta_{7}=-1.7940$, $\beta_{8}=7.7106, \beta_{9}=0.5256, \beta_{13}=0.0240$ であり、 $D N_{i}$ は上 

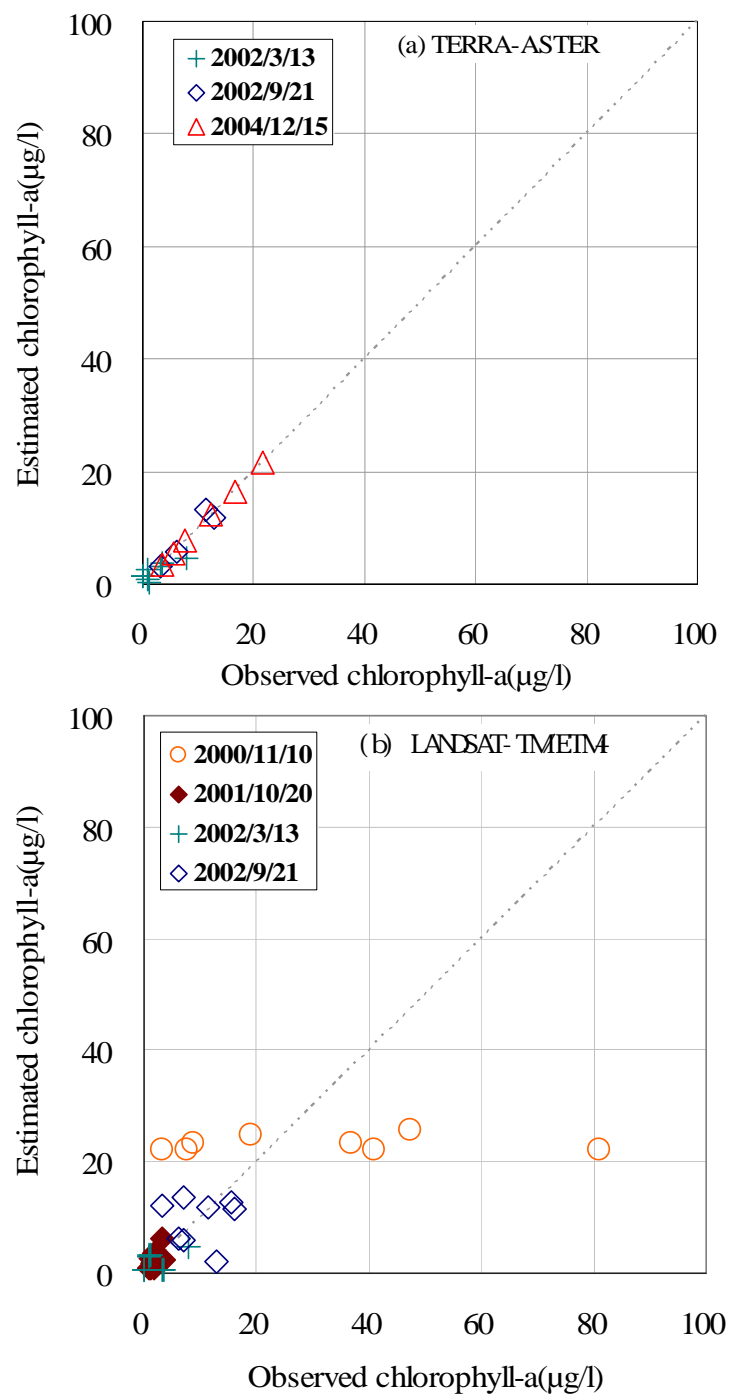

図 - 6 (a) (b) TERPA ASTER画像・ LANDSATTMETMAによる推定クロロフィルa濃度と実測 值の比較

述と同樣、各バンドのデジタルナンバーである。

図 - 4 (a) にTERRA ASTER画像により求めた推定透明度 と観測值の比較を示す。一方、図 - 4 (b) にはLANDSATTMETA画像による推定透明度と実測値の比較を示して いる。前者の $R^{2}$ は 0.7689 、後者は0.4678であつた。推定 精度の違いの理由は、海水面温度の時と同じと考えられ るが、一方、LANDSATでは、1998/4/27の観測における 一部の透明度の高い測定データがうまく再現されていな いため精度を落としていると言える。ASTERの場合の 透明度か高い水域での比較検討が必要である。図 - 5 に は光れ光れの観測点における透明度の推定値と実測值を 比較した図を示している。2002/3/13の推定透明度は観測 値と少し食い違っているが、許容できる範囲である。 2004/12/15においては、推定透明度は観測值とほとんど 一致している。

(3) クロロフィルa濃度
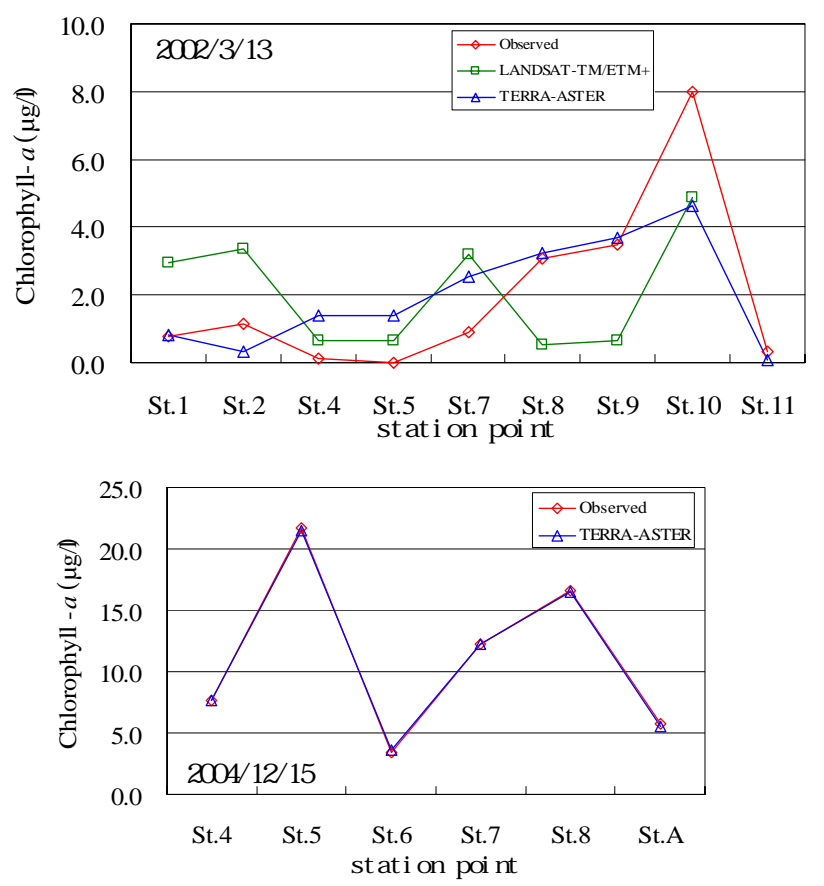

図 - 7 クロロフィルa濃度の 推定精度比較

クロロフィルa濃度は水中の植物プランクトン量を表 す指標としてしばしば用いられる。有明海の2000年のノ リ不作は、直接的には植物プランクトンの異常増殖によ るものであると結論づけてある。

線形回帰解析により、以下のようにASTER画像による クロロフィルa濃度 $(\mathrm{OH})$ の推定式が得られた。

$$
\begin{aligned}
C H L=m & +\gamma_{1} D N_{1}+\gamma_{2} D N_{2}+\gamma_{3} D N_{3}+\gamma_{6} D N_{6} \\
& +\gamma_{7} D N_{7}+\gamma_{8} D N_{8}+\gamma_{9} D N_{9}+\gamma_{13} D N_{13}
\end{aligned}
$$

ここで、弚れ光れの定数は、 $m=-19.1775, \gamma_{1}=0.2404$, $\gamma_{2}=0.7241, \quad \gamma_{3}=0.6714, \quad \gamma_{6}=-1.9499, \quad \gamma_{7}=2.9247$, $\gamma_{8}=-7.9891, \gamma_{9}=-0.2075, \gamma_{13}=0.0523$ である。

図－6(a) は、TERRA ASTER画像を用いて推定したクロ ロフィルa濃度と実測值の比較を表したグラフである。 一方、図 - 6 (b) はLANDSAT- TMETAA画像による推定クロ ロフィルa濃度と実測值との比較図である。光れぞれの 決定係数は、前者か $R^{2}=0.9667$ 、後者か $R^{2}=0.4509$ であつ た。LANDSAT-TM/ETM+においては、高い濃度のクロ ロフィルa濃度の時、特に2000/11/10で大きな誤差が表れ ている。図 - 7 は、観測地点毎の推定クロロフィルa濃 度と実測値との比較を示している。2004/12/15では、ほ ぼ完全に推定クロロフィルa濃度と実測濃度の值が一致 している。この日のクロロフィルa濃度は比較的高いが TERPA ASTER画像による回帰モデルはLANDSATの場合に比 べてより高い精度て推定していると言えるであろう。光 の理由としては、クロロフィルa濃度の場合、特に可視 域バンドの空間解像度の違いが大きく効いているのでは ないかと考えられる。現地観測の際にもクロロフィルa 
濃度が高い水塊が見られ、30mの解像度では光れが捉え にくかったのではないかと思われる。

\section{5 . 湾奥における海水面温度分布の推定}

有明海湾奥部の海水面温度を式( 1)により推定した。 2002/3/13ならびに2002/9/21に取得されたTERRA ASTER 衛星画像を幾何補正・大気補正後に海水面温度分布に変 換した画像が、図-8である。この図によれば、干潟付 近の水面温度は他に比較してより高い值を示しているの が分かる。これは、河川からの流出並びに春と初秋の日 中の浅海域であることなどか理由であると考えられる。 さらに、諫早湾と諫早干拓付近においても高い海水面温 度が分布していることが分かる。このように衛星画像を 利用することで、これらの樣子か面的に確かめられる。

\section{6 . 結論}

有明海における水質観測データを利用することで、海 水面温度、透明度、クロロフィルaなどの水質指標を推 定するモデルを構築することができた。このモデルは、 TERRA ASTER衛星画像よりこれらの水質指標を取り出す ことを可能にするモデルである。TERRA ASTERと LANDSAT- TMETMAによる推定結果を比較することで、前 者の方か洧明海湾奥部の水質推定に関してはより高い精 度を持っていることか確忍できた。本研究の成果は、有 明海湾奥部における将来の環境特性を理解するのに有効 に活用可能であることが分かった。

謝辞 : 本研究は、平成16年度佐賀大学学内CEの研究助 成の支援を得て行われたものである。研究を進めるにあ たり、当時学部 4 年生であつた押川典由君の多大なる協 力を得た。記して感謝の意を表する。さらに、LANDSATTMETMA衛星画像は独立行政法人宇宙航空研究開発機構 (JAXA) より、TERRA ASTER衛星画像は財団法人資源・環 境観測解析センター( ERSDAC) より提供を受けたものであ ることを付記する。

\section{参考文献}

1) Gan, T.Y., Ohgushi, K. and Araki, H.: "Estimating water quality of the Ariake Sea in Japan using Landsat-TM data -Evaluation of SDD and SST -“, Lowland Technology International, Vol.2, No.1, 47-64, 2000.

2) Ohgushi, K., Gan, T.Y. and Araki, H.: “A study on estimation of

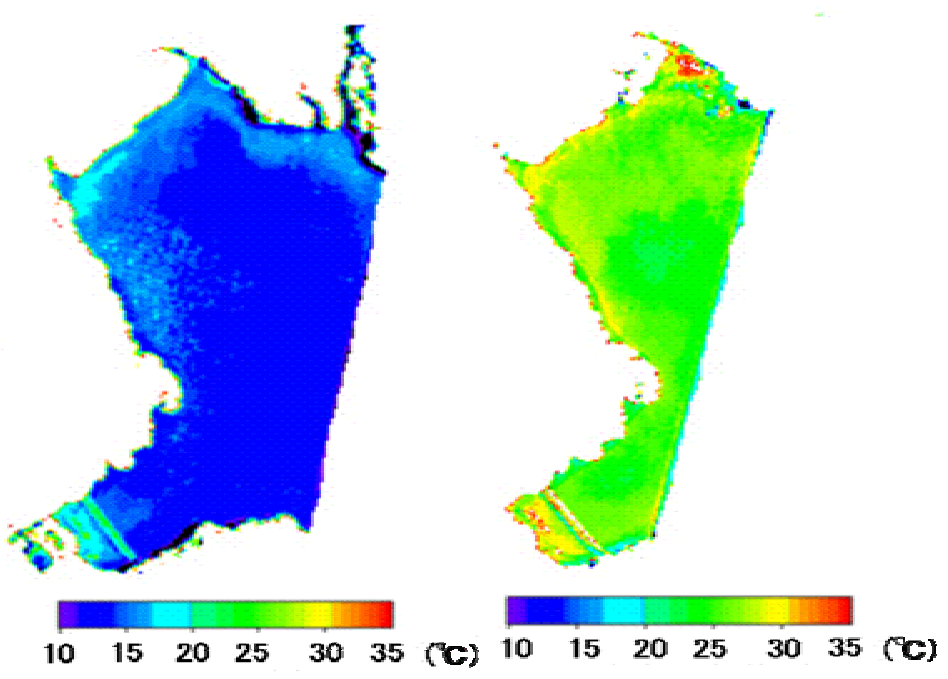

図 - 8 TERRA ASTER画像により得られた海水面 温度分布(左 : 11: 12JST, 2002/3/13, 右 : 11: 12 ST, 2002/9/21)

water environment in Ariake Sea using remotely sensed data“, Proc. of 12th Congress of APD-IAHR, Bangkok, Vol.2, 597-607, 2000.

3) Ohgushi, K., Araki, H and Gan, T.Y.: "Water quality monitoring of the Ariake Sea by remote sensing and utilization of field observation“, Lowland Technology International, Vol.6, No.2, 1-9, 2004.

4) 桐本賢太・河原洋平・緒方純俊 : ASTERおよびSAR画像に 有明海の環境観察、日本リモートセンシング学会学術講演会 論文集、Vol.33, 193-194, 2002.

5) Leica Geosystems GIS \& Mapping, LLC. : ERDAS IMAGINE Tour Guides, 2801 Buford Highway, NE, Atlanta, Georgia 30329-2137, USA, 2003.

6) Geosystems GmbH. : ATCOR for ERDAS IMAGINE User Manual, Riesstrasse 10, D-82110, Germany, 2002.

7) Kneizys, F.X., E.P. Shettle, L.W. Abreu, J.H. Chetwynd, G.P. Anderson, W.O. Gallery, J.E.A. Selby and S.A. Clough: Users Guide to LOWTRAN7, AFGL-TR-88-0177 Geophysics Directorate/GPOS, 29 Randolph Rd., Hanscom AFB, MA 017313010, USA, 1988.

8) 農林水産省ノリ不作等対策関係検討委員会 : 最終報告書 - 有 明海の漁業と環境の再生を願って - , 2003.

(2005. 9. 30受付) 